\title{
Economic Valuation of Nature-Based Tourism Object in Rawapening, Indonesia: An Application of Travel Cost and Contingent Valuation Method
}

\author{
Arif Rahman Hakim (Corresponding author)
}

Faculty of Economics, University of Indonesia

PO BOX 16424, Indonesia

Tel: 62-21-786-7222Ｅ-mail: arif.rahman81@ui.ac.id; arhaqkm@gmail.com

Sri Subanti

Faculty of Mathematics and Natural Science, Sebelas Maret University

PO BOX 57126, Indonesia

Tel: 62-271-646-994 E-mail: sri.subanti@uns.ac.id

Mangara Tambunan

Faculty of Economics, University of Indonesia

PO BOX 16424, Indonesia

Tel: 62-21-786-7222Ｅ-mail: mangara.t@ui.ac.id

Received: Septermber 2, 2010

Accepted: March 1, 2011

doi:10.5539/jsd.v4n2p91

\begin{abstract}
The purpose of this study is to measure the economic value in Rawapening. This study is expected to be able to see how far the role of nature tourism is seen as an environmentally sound tourist attractions. Because the benefits of natural attractions usually have a variety of natural resources such as biodiversity, benefit directly, and indirectly related to important ecological functions that are not only considered as a tourist attraction.

This study was used primary data. The primary data obtained from field surveys to the perpetrator who was visiting tourist Rawapening. The analytical method used two methods. There are travel cost method and contingent valuation method.

The study was found significant factors the determinant of the probability of individuals to be willing to pay a certain nominal value for environmental quality improvement are nominal amount bid, income, and education. Then, the determinant of the number of visits are an experience to visit, travel costs, income, age, and perception. The economic value of ecotourism was estimated at $\mathrm{Rp} 7,41$ billion for consumer surplus and $\mathrm{Rp} 1,65$ billion for total benefit per year. This implies that the significant economic value of nature based tourism will be lost from any large scale development by degrading natural environment.
\end{abstract}

Keywords: Economic valuation, Ecotourism, Travel cost method, Contingent valuation method, Rawapening

\section{Introduction}

Indonesia is a country blessed with natural wealth and diversity. Indonesia also has a tropical natural beauty and cultural heritage. In addition, Indonesia has a cultural center with a diverse population. This gifts are unique, if developed and managed properly will be very potential for tourism development. In future, the optimal management of tourism can provide sustainable economic benefits.

One of environmental friendly tourism is ecotourism. Ecotourism is often referred as environmentally sound tourism. Ecotourism is one of outdoor management recreation that based on a commitment with nature conservation and environment. Ecotourism can be a major alternative for urban societies on the needs of recreation. Because recreation has become human needs to refresh the mind and the body condition after undergoing daily life routines for each individu. 
Rawapening is one of ecotourism which is located in Semarang Regency, Central Java Province, Indonesia. Physically located in four districts, including Banyubiru, Tuntang, Bawen, and Ambarawa. From figure 1, we can show the location of Rawapening.

Rawapening divided into six sub area. There are sub area Tlogo, Lopait, Muncul, Asinan, the Cinta-Brawijaya Hill, Asinan, and Pendem Castle. From table 1, we can show six sub area in Rawapening. This table describes a big picture of Rawapanieng because it includes wides, village, and district in Sub Area of Rawapening.

Rawapening have various and unique potential tourism. The main potential are interesting views, includes direct view or indirect view to Rawapening. Besides that, another potential tourism in Rawapening, likes agro tourism, cultural tourism, and antique train tourism. In addition, Rawapening located in strategic location. Because Rawapening covered gold triangle road that connected Yogyakarta - Solo - Semarang (Joglosemar). This location were closed with excellent and pledge tourism object in Central Java Province ( Tourism Department, Central Java Province, 2009 ).

Rawapening ("reel" derives from "clear") is a lake as well as a tourist attractions in Semarang Regency, Central Java. With an area of 2670 hectares, it occupies Ambarawa District, Bawen, Tuntang, and Banyubiru. Rawapening located in the lower basin slopes of Mount Merbabu, Mount Telomoyo, and Mount Ungaran. The lake is experiencing rapid silting. Never a place for fishing, is now almost the entire surface is covered with water hyacinth marsh. Weeds are also already covered Tuntang River, especially in the upstream. Business address invasive species is done by performing cleaning and training utilization of water hyacinth in the craft, but the pressure of plant populations are very high.

Rawapening has decent potential to be developed. Rawapening tourism potential are the charm of nature, cultural communities, and attractions are being built or not. Potential natural scenery, among others, a beautiful lake or swamp, a fairly cool climate is perfect for rest place, coffee plantations, and hilly topography which can provide varied atmosphere. Another potential in Rawapening such as community cultural life of rural communities, traditional art, traditions and customs, handicraft industry, and others.

However, the development of ecotourism such as Rawapening should not be treated as economic goods but as public goods. This treatment is associated with rehabilitation, development, and utilization for ecotourism. This effort can make the evaluation in line with economic principle. Although we know that natural tourism have different benefits.

By looking at the background description above, initial analysis concentrated on the determinant of the number of visits and the probability of individuals to be willing to pay a certain nominal value for environmental quality improvement. Then, measuring the economic value of natural based tourism object in Rawapening. A comparison of the results is made and conclusions are derived with respect to recommendations and policy implications.

\section{Methodology}

\subsection{Methods and Survey Instruments}

In this study, the survey concentrated on the visitors in Rawapening for a number of reasons. As mail or telephone survey proved unsuccessful in gathering correspondents willingness to pay figures, it was anticipated that it would be difficult to obtain survey from visitors outside Rawapening. Thus, individual visitors instead of households were chosen as respondents for interview. Visitors was broadly defined as those who use the lake for recreation. This meant that people who lived by the lake must be counted as visitors if they take a walk or cycle around the lake for relaxation. However, passerby, employees in the administrative and services sector of the lake area, and those in the area for business purpose were not counted. The visitors were randomly chosen for the interviews that completed the questionnaire.

Three undergraduate were trained to undertake the survey. Each of the trained interviewers was responsible for one or two locations where he/she distributed the questionnaire to respondents and offered explanations and assistance in completing the questionnaire. The presence of an interviewer was considered necessary to ensure a proper completion of the survey sheet and a high return rate.

In total, 300 copies of the questionnaire were prepared and distributed by interviewers. Of the 250 questionnaires returned, 225 could be used for TCM and CVM analysis. Of 25 invalid replies, 18 did not complete the questions (including 8 with illegible responses ) and 7 were considered inconsistent with their WTP.

The questionnaire consisted of five sections, covering (1) information objects of study and research purposes, (2) motivations, desires, and activities of the respondent, (3) demographic characteristics of respondents; (4) 
respondents perception towards tourism, and (5) respondents rating for environmental services of a tourist attraction. Questionnaire consisted of multiple choice questions, dichotomous yes or no, and rank-ordered response. In addition there is also an open question that is useful to provide further explanation and offer real value to the ticket if there was an increased quality of tourism in the area Rawapening.

To measure individual's WTP, a survey that employs a dichotomous choice questionnaire is used. The DC approach was first employed by Bishop and Heberlein (1979). Respondents in the DC approach are asked to accept or reject a suggested price under hyphothetical market situation. They only need to answer "yes" or "no" when presented with a price. It is easier for respondents to answer because respondents are familiar with this methods ( Hanemann, 1994 ). Lockwood and Tracy (1995) says that, the DC format is generally considered to be a superior elicitation method. A direct face to face survey method was employed. This method was selected, because it is more likely to elicit reliable estimates of preservation value with its strength in achieving higher response rates than mail surveys ( Lee and Han, 2002 ).

\subsection{Payment Options}

Payment option is very important for researchers to select a payment option within the contingency valuation survey. This payment option scenario represents willingness to pay of respondents. Many payment options that can be used as entrance fees, sales tax, utility bills, license fees, or endowment funds. However, the entrance fee into the payment options on this survey. Lee ( 1997 ) and Barral et.al ( 2008 ) used entrance fee as payment options in their study. Because, an entrance fee as realistic and appropriate payment vehicle, since it would be a logical and realistic payment vehicle for users of recreational services. The contingent valuation scenario was carefully worded for the respondents, because it was stated in hyphotetical market scenario.

\subsection{Hyphotetical Market Scenario}

Scenario market hypothesis in this study to obtain valid responses from respondents. The first question in the form of contingency valuation "if the sights Rawapening improved so that better management of the environment, natural resources, fishing, culture, swimming, farming, and recreation. Would you agree if the admission price was increased by Rp Y, - per person? ".

\subsection{Model Specification}

Model established in the study of contingency valuation method assumes that individuals in this visitor attractions will receive offers admission price to maximize their utility, which can be described in the following equation (Hanemann, 1984; Bowker \& Stoll, 1988; Lee, 1997 ; Lee \& Han, 2002; Adjaye \& Tapsuwan, 2008):

$$
V(1, Y-A ; S)+\varepsilon_{1} \geq V(0, Y ; S)+\varepsilon_{0}
$$

and vice versa, or in this case the individual visitor attractions will reject the bid price of admission if not able to maximize utilitinya, this condition can be described as follows:

$$
V(1, Y-A ; S)+\varepsilon_{1} \leq V(0, Y ; S)+\varepsilon_{0}
$$

In both the above equation $\mathrm{V}$ is the indirect utility function, $\mathrm{Y}$ is income (household income per month), $\mathrm{A}$ is the bid or offer price of admission, $\mathrm{S}$ represents socio-economic characteristics of individuals or known by demographic characteristics, as well as $\varepsilon_{0}$ and $\varepsilon_{1}$ is the stochastic component, variable random independently distributed with mean zero or known by the independently distributed random variables with zero mean.

Form of the equation above, according to Bowker \& Stoll (1988) has been described previously Hanemann, a theoretical model of hicksian compensating and equivalent surpluses that can be obtained from the dichotomous choice, discrete response data. In this case, Hanemann follow a framework willingness to pay (WTP) for a measurement of the individual or the individual surplus equivalent surplus. Individual respondents are assumed to know their utility functions are determined from the following variables ie income, whether there is any improvement attractions, and individual demographic conditions. While other variables such as price, as a simplification, is assumed to be unchanged. Since there are random components that can not be observed on an individual utility function, utility is treated as random variables with parametric probability distribution that has the mean or the mean $V(A, Y, S)$ and the stochastic component $\varepsilon_{\mathrm{w}}$ independent and identically distributed random variables with zero mean.

Then, the difference between the response of the utilities that do not agree with the bidding price of admission, defined in the following equation:

$$
\Delta \eta=V(1, Y-A ; S)-V(0, Y ; S)+\left(\varepsilon_{1}-\varepsilon_{0}\right) .
$$


The above equation forms the postscript is a dichotomous choice contingent valuation format is a binary choice methods and dependent variables, thus requiring a qualitative choice model or a qualitative choice model, where there are two options namely logit model or probit model. This study chose to use logit model compared probit model. According to the explanation of the Hill, Griffiths, \& Judge (2001), in Adjaye \& Tapsuwan (2008) that the logit model is formed based on the cumulative distribution, while probit model was established based on the normal distribution and is numerically more complicated in the estimate. This question was also confirmed by the Bishop \& Heberlein (1979) and Sheller, Stoll, and Chavas (1985) in Lee (1997) which states that the logit model is chosen relatively more than the probit model, as well as in many other similar studies, including recreation, because this model is relatively easy to calculate.

Furthermore, individuals who are faced with a choice of whether to accept or reject the bid level market hypothesis, would have a probability $(\mathrm{Pi})$, where the individuals who will receive offers ticket prices could be expressed in logarithm or log-logit model as follows:

Prob ( yes )

$$
\begin{aligned}
& =F \eta \Delta \eta \\
& =\left(1+e^{-\Delta V}\right)^{-1} \\
& =\frac{1}{1+e^{-\left(\alpha+\beta_{1} A+\beta_{2} Y+\beta_{3} S\right)}} .
\end{aligned}
$$

Where $F \eta$ is the cumulative distribution function, $\alpha$ is intercept, and $\beta_{i}$ represents the coefficient of the variable price offer admission, income, and demographic conditions. The estimated coefficient for $\beta_{1}, \beta_{2}$ dan $\beta_{3}$ is $\beta_{1} \leq 0 ; \beta_{2}>0$; and $\beta_{3}>0$ vice versa $\beta_{3}<0$. In econometric form, can be written as follows :

$$
\text { PROB }_{i}=\gamma+\delta_{1} \text { Bid }_{i}+\delta_{2} \text { SOCECON }_{i}+\delta_{3} \text { PERCP }_{i}+\mu_{i}
$$

Logit model in equation (2.4) above, then estimated using the method of maximum likelihood (ML), which is a technique commonly used to estimate the logit model. Furthermore, the parameters have been estimated using the ML method, is calculated its value expected WTP through numerical integration, in the range from 0 up to a maximum ticket price offer, as can be seen in the following equation below :

$$
\begin{aligned}
\mathrm{E}(\mathrm{WTP}) & =\int_{0}^{\operatorname{Max} A} F \pi(\Delta V) d A \\
& =\int_{0}^{\operatorname{Max} A}\left(\alpha^{*}+\beta A\right) d A
\end{aligned}
$$

Where E (WTP) is the expected value of the WTP, and $\alpha *$ is the adjusted intercept obtained by inserting the average value of each independent variable into the equation for the regression model then calculated the utility of his difference. Form of equation (3.5) above is often called the truncated mean WTP. According to Duffield \& Patterson (1991) in Lee \& Han (2002) and Lee \& Mjelde (2007), the calculation of WTP by numerical integration techniques with a range of 0 to Max (bid) is the best method because it is consistent with the theory, statistical efficiency, and ability to can be aggregated.

Next, the travel cost model in this study assumes that the individual's demand for recreation to places affected by the cost of travel, individual preferences, as well as socioeconomic characteristics or socio-economic or demographic characteristics. Thus, the function of the model to be estimated is as follows:

$$
\text { VISITS }=\mathrm{f}\{\mathrm{TC}, \text { EXPER, PERCP, SOCECON }\} .
$$

Where the number of visits for each individual who is a postscript to the proxy of demand for recreation to individuals affected by the attractions of travel costs, individual preferences, and socioeconomic characteristics. In econometrics, the equation (3.6) above can be written again as follows:

$$
\text { VISITS }_{i}=\alpha+\beta_{1} \text { TC }_{i}+\beta_{2} \text { EXPER }_{i}+\beta_{3} \text { SOCECON }_{i}+\beta_{4} \text { PERCP }_{i}+\varepsilon_{i}
$$

Travel cost model trying to estimate the dependent variable is the number of visits that an individual or a respondent who is affected by the independent variable, which in this case the independent variables such as travel expenses, visited experiences, socioeconomic characteristics, and respondent preferences. Techniques used to estimate the ordinary least square. According Gujarati, 2004 and Nachrowi et.al, 2006 says that OLS estimation must have released from classical assumption. One thing to be aware that this study did not calculate an annuity visitor spending but spending visitors only at the time of their visits to area attractions Rawapening so 
it is assumed that the respondents do not visits to Rawapening after the survey period. The description of the variables used in equation 2.5 and 2.8 will be explained in table 2 .

\section{Results}

\subsection{Demographic Profile of Respondents}

Based on table 3 , the proportion of male respondents $(78,67 \%)$ is similar to female respondents $(21,33 \%)$. The marital status of respondents with married status represent $50,22 \%$. It's greater than single status, represent $49,78 \%$ of respondents. Age groups were also relatively distributed, except for people age $46-55$ or older. Majority respondents have attended senior high school, eventhough many respondents have attended colleges or university graduates. Respondents that have attended senior high school or less, represent $57 \%$ of respondents, whereas $17 \%$ of the respondents had colleges or universities graduates.

From job sides, majority of respondents work as students that visiting Rawapening than others, eventhough not different from respondents who work as entrepreneurs. The percentage of both, $27 \%$ of student respondents and $24 \%$ of entrepreneurs respondents. Persons with a monthly household income of 1,51 - 2 million rupiah and $2-$ 2,5 million rupiah accounted for $29,78 \%$ and $32,44 \%$. While those, respondents with incomes less than 1,5 million rupiah represented $21,33 \%$. Only $4 \%$ of respondents had incomes over 3 million rupiah.

\subsection{Estimation Results}

Based on table 4, for travel cost method, the number of tourist visits in Rawapening influenced by experience (exper), travel costs (travel costs), income respondents per month (income), age (age), gender (gend), education level (educ), and perception. Then, for contingent valuation method, the determinant of the probability of individuals to be willing to pay a certain nominal value for environmental quality improvement are nominal amount bid (bid), respondents income per month (income), and education level (educ).

From table 4, we can be obtained that the significant factors influence the number of visits are experience (exper), travel costs (tc), the respondents monthly income (income), age (age), respondent perceptions associated with the decision to general visit attractions in Rawapening (persp1), and respondent perceptions associated with the preference for tourism attraction in Rawapening (persp4).

From table 4, we can be known that the significant factors influence the willingness to pay for respondents accepted the offer price of tickets in the market hypothesize scenario in Rawapening are nominal admission price to a market hypothesis that is given to respondent (bid), monthly respondents income (income), and educational level of respondents (educ).

Another variable is not significant, such as age and sex suggest that visitors who come into a tourist attraction in Rawapening not segmented in the range of age groups and specific gender, as shown in demographic profile (see table 3). Instead, visitors will also not provide a good assessment for tourism in Rawapening.

\subsection{Economic Value in Rawapening}

Results in table 5 shows that the value of consumer surplus in Rawapening reached Rp 7,410 billion. When compared with the value of benefits per year Rawapening reached Rp 1,654 billion. Of course this comparison pretty far. However, when calculated with the monetary value can be seen that visitors who come to Rawapening enormous benefit.

If you see the results above, it should be a commitment to the preservation of natural and social responsibility. For that we need no support from the residents around and visitors to the area of tourism development program Rawapening. In addition, with attention to the environmental costs, including the existence of value, or price of natural resource use over time or between generations, future generations can be expected to contribute to enjoy the natural beauty and the benefits are felt by the current generation.

\section{Conclusion}

Our empirical study show that significant factors affecting the probability of individuals to be willing to pay a certain nominal value for environmentally sound management of tourism is the nominal amount bid, income, and education. Conversely, a significant factor influencing the number of visits is an experience to visit, travel costs, income, age, and perception. This result represents that contingent valuation was independent of travel cost and the number of visits a respondent actually made. This method was heavily dependent on income, education, and the judgement of respondent on environment quality improvement in Rawapening. According to Tambunan (2002), the public good element plays an important role in the formulation of respondent answers. Because, it's possible that respondents had been told why the entrance fee was being charged in Rawapening. 
In addition, the value of consumer surplus and the value of benefits in the Regions Rawapening apparently given the finding that the value of consumer surplus is greater than the benefits. This study is in line with the findings of Du Yaping (2003) and Mayor et al (2007). The value of consumer surplus in Rawapening amounted to Rp

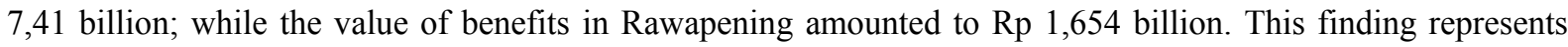
that contingent valuation measurement does not exclude non use values. Therefore, respondents were willing to pay not only for their own consumption, but also for other reasons in related to their own recreational uses of the lake.

Recommendations that can be given to local governments should have to raise the price of entrance fee at Rawapening, because benefits and consumer surplus is very high. It used to improve environmental quality tourism in Rawapening. Suggestions related to the development of the following areas of study for local governments are need to hear suggestions from visitor-related development and management in Rawapening. In addition, local government as policy maker must be taken to discourage free riders and to elicit payment for better quality. Funding for sustainable rawapening tourism management program would also be financially feasible if the current entrance fee were not to be increased.

\section{References}

Adjaye, John Asafu and Sorada Tapsuwan. (2008). A Contingent Valuation Study of Scuba Diving Benefits: Case Study in Mu Ko Similan Marine National Park, Thailand. Tourism Management, 29, 1122 - 1130.

Barral, Nabin, Stern, Marc J, and Ranju Bhattarai. (2008). Contingent Valuation of Ecotourism in Annapura Conservation Area, Nepal: Implications for Suistanable Park Finance and Local Development. Ecological Economics, 66, 218 - 227.

Bishop, Richard J and Thomas A Heberlein. (1979). Measuring Values of Extramarket Goods: Are Indirect Measured Biased?". American Journal of Agricultural Economics, 61 (December), 926 - 930.

Board of Regional Planning and Development. (2009). Book of Technical Planning in Rawapening Tourism. Semarang Regency, Central Java Province, Indonesia.

Bowker, J M and John R Stoll. (1988). Use Dichotomous Choice Non Market Methods to Value the Whooping Crane Resource. American Journal of Agricultural Economics, 70, 372 - 381.

Gujarati, Damodar. (2004). Basis Econometrics $4^{\text {th }}$ Edition. New York: McGrawHill.

Hanemann, MW. (1984). Welfare Evaluations in Contingent Valuation Experiments with Discrete Responses. Journal of American Agricultural Economics, 66 (3), 331 - 341.

Hanemann, MW. (1989). Welfare Evaluations in Contingent Valuation Experiments with Discrete Responses Data: Reply. Journal of American Agricultural Economics, 71 (4), 1057 - 1061.

Hanemann, MW. (1994). Valuing the Environment through Contingent Valuation. Journal of Economic Perspectives, 8 (4), 19 - 43.

Lee, Chong-Ki. (1997). Valuation of Nature-Based Tourism Resources Using Dichotomous Choice Contingent Valuation Method. Tourism Management, 18, 587 - 591.

Lee, Chong-Ki and Sang-Yoel Han. (2002). Estimating the Use and Preservation Values of National Parks Tourism Resources Using a Contingent Valuation Method. Tourism Management, 23, 531 - 540.

Lee, Chong-Ki and James W Mjelde. (2007). Valuation of Ecotourism Resources Using a Contingent Valuation Method: The Case of the Korean DMZ. Ecological Economics, 63, 511 - 520.

Lockwood, M and K. Tracy. (1995). Nonmarket Economic Valuation of An Urban Recreation Park. Journal of Leisure Research, 27 (2), 155 - 168.

Mayor, Karen, Sue Scott, and Richard S J Tol. (2007). Comparing the Travel Cost Method and the Contingent Valuation Method - An Application of Convergent Validity Theory to the Recreational Values of the Irish Forests. ESRI Working Paper. Anline] Available: http://www.esri.ie/UserFiles/publications/20070426114616/WP190.pdf (January 18, 2011).

Nachrowi, Nachrowi D and Hardius Usman. (2006). Practice and Popular Econometrics Approach in Economy and Finance Analysis. Jakarta: University of Indonesia.

Sri Rejeki, Ikeu. (2005). Demand Analysis Benefits Environmental Services Pangrango Gunung Gede National Park: Comparison Between the Method of Travel Cost and Contingency Valuation Method, Unpublished Master Thesis. University of Indonesia, Indonesia. 
Tambunan, Mangara. (2002). The Economic of Natural Resources and Environment. Course Material for Graduate Student. University of Indonesia, Indonesia.

Tourism Department. (2009). Tourism Investment Profile in Rawapening. Central Java Province, Indonesia.

Yaping, Du. (2003). The Value of Improved Water Quality for Recreation in East Lake, Wuhan, China: An Application of Contingent Valuation and Travel Cost Methods. EEPSEA Research Report Series. [Online] Available: http://idl-bnc.idrc.ca/dspace/bitstream/10625/16629/6/108377.pdf (January 18, 2011).

Table 1. Sub Area in Rawapening

\begin{tabular}{|c|l|c|l|l|}
\hline No & \multicolumn{1}{|c|}{ Sub Area } & Wide ( Ha ) & \multicolumn{1}{|c|}{ Village } & \multicolumn{1}{c|}{ District } \\
\hline 1 & Tlogo & 412 & $\begin{array}{l}\text { Lopait } \\
\text { Tuntang } \\
\text { Tlogo } \\
\text { Delik } \\
\text { Watuagung }\end{array}$ & Tuntang \\
& & & Lopait & \\
\hline 2 & Lopait & 15 & $\begin{array}{l}\text { Kebondawa } \\
\text { Rowobone }\end{array}$ & Tuntang \\
\hline 3 & Cinta-Brawijaya Hill & 40 & Rowobone & Banyubiru \\
\hline 4 & Muncul & 424 & Asinan & Bawen \\
\hline 5 & Asinan & 14 & Banyubiru & Banyubiru \\
\hline 6 & Pendem Castle & & \\
\hline
\end{tabular}

Source : Book of Technical Planning in Rawapening Tourism,

Board of Regional Planning and Development, Semarang Regency, Central Java Province, Indonesia ( 2009 )

Table 2. Variables Used in the Model

\begin{tabular}{|c|c|}
\hline Variable & Description \\
\hline PROB & $\begin{array}{l}\text { Dependent variable, } 1 \text { if the respondent received a bid price of the ticket, } 0 \text { if the } \\
\text { respondent refused admission price quote }\end{array}$ \\
\hline BID & Offer admission to respondent for a given market hypothesis \\
\hline \multicolumn{2}{|c|}{ Demographic Profile } \\
\hline INCOME & Income respondent per month \\
\hline GEND & Sex, 1 if male, 0 if female \\
\hline EDUC & Time attained for formal education \\
\hline AGE & Age \\
\hline \multicolumn{2}{|l|}{ Persepsi } \\
\hline PERCP1 & $\begin{array}{l}\text { Respondent perceptions associated with the decision to general visit attractions in } \\
\text { Rawapening }\end{array}$ \\
\hline PERCP2 & $\begin{array}{l}\text { Respondent perceptions associated with the decision to specific visit attractions in } \\
\text { Rawapening }\end{array}$ \\
\hline PERCP3 & $\begin{array}{l}\text { Respondent perceptions associated with the views of sustainability attractions functions } \\
\text { in Rawapening }\end{array}$ \\
\hline PERCP4 & $\begin{array}{l}\text { Respondent perceptions associated with the preference for tourism attraction in } \\
\text { Rawapening }\end{array}$ \\
\hline
\end{tabular}


Table 3. Demographic Profile of Respondents in Rawapening

\begin{tabular}{|l|r|}
\hline \multicolumn{1}{|c|}{ Characteristics } & Percentage \\
\hline Sex & \\
Female & 21.33 \\
Male & 78.67 \\
\hline Marital Status & \\
Single & 49.78 \\
Married & 50.22 \\
\hline Age & \\
$16-25$ & 38.67 \\
$26-35$ & 42.22 \\
$36-45$ & 13.33 \\
$46-55$ & 4.44 \\
$>55$ & 1.33 \\
\hline Education & 82.21 \\
High School or Less & 14.67 \\
Graduate & 3.11 \\
Master & \\
\hline Occupancy & 27.11 \\
Student & 12.44 \\
Government Staff & 19.11 \\
Private Staff & 3.56 \\
Pension & 24.00 \\
Entrepreneur & 13.78 \\
Others & \\
\hline Monthly Household Income (1US\$ Rp & 29.78 \\
9150 ) & 32.44 \\
$1,0-1,50$ million & 12.44 \\
$2,01-2,5$ million & \\
$2,51-3,0$ million & \\
$>=3,01 \quad$ million & \\
\hline
\end{tabular}


Table 4. Estimation Results in TCM and CVM

\begin{tabular}{|c|c|c|c|}
\hline Variable & $\begin{array}{c}\text { Travel } \\
\text { Cost } \\
\text { Method } \\
\text { (TCM) }\end{array}$ & Variabel & $\begin{array}{l}\text { Contingent } \\
\text { Valuation } \\
\text { Method } \\
\text { (CVM) }\end{array}$ \\
\hline Exper & $\begin{array}{r}-0.54457 * * \\
-0.05912\end{array}$ & & \\
\hline TC & $\begin{array}{r}-0.32774 * * \\
-0.07441 \\
\end{array}$ & Bid & $\begin{array}{r}1.50163 * * \\
-0.23485\end{array}$ \\
\hline Income & $\begin{array}{r}0.17581 * * \\
-0.07334\end{array}$ & Income & $\begin{array}{l}0.28094^{*} \\
-0.17486\end{array}$ \\
\hline Age & $\begin{array}{r}0.22387 * * \\
-0.0614\end{array}$ & Age & $\begin{array}{l}-0.20758 \\
-0.23377\end{array}$ \\
\hline Gend & $\begin{array}{r}0.01262 \\
-0.05287\end{array}$ & Gend & $\begin{array}{r}0.21403 \\
-0.44715\end{array}$ \\
\hline Educ & $\begin{array}{l}-0.06728 \\
-0.06662\end{array}$ & Educ & $\begin{array}{l}0.74907 * * \\
-0.27049\end{array}$ \\
\hline PERCP1 & $\begin{array}{r}-0.14890 * * \\
-0.05794\end{array}$ & PERCP1 & $\begin{array}{l}0.23516 \\
-0.2186\end{array}$ \\
\hline PERCP2 & $\begin{array}{r}0.07937 \\
-0.05775\end{array}$ & PERCP2 & $\begin{array}{l}-0.10184 \\
-0.18143\end{array}$ \\
\hline PERCP3 & $\begin{array}{l}-0.04805 \\
-0.05438\end{array}$ & PERCP3 & $\begin{array}{r}0.01185 \\
-0.16727\end{array}$ \\
\hline PERCP4 & $\begin{array}{r}0.16298 * * \\
-0.05529\end{array}$ & PERCP4 & $\begin{array}{r}0.01101 \\
-0.17165\end{array}$ \\
\hline $\mathrm{R}^{2}$ & 0.47226 & McFadden $\mathrm{R}^{2}$ & 0.32192 \\
\hline F-stat & 19.15006 & LR statistic (9 df) & 98.44465 \\
\hline \multicolumn{2}{|c|}{$\begin{array}{ll}* * & : \text { sig. } \alpha=5 \% \\
* & : \text { sig. } \alpha=10 \%\end{array}$} & $\begin{array}{l}\% \text { of Right } \\
\text { Prediction }\end{array}$ & 77.33 \\
\hline
\end{tabular}

Table 5. Benefit Value and Surplus Per Year ( Rp )

\begin{tabular}{|l|c|}
\hline Variable & Value \\
\hline Benefit Per Year & 1.654 .893 .456 \\
Surplus Per Year & 7.410 .798 .912 \\
\hline
\end{tabular}




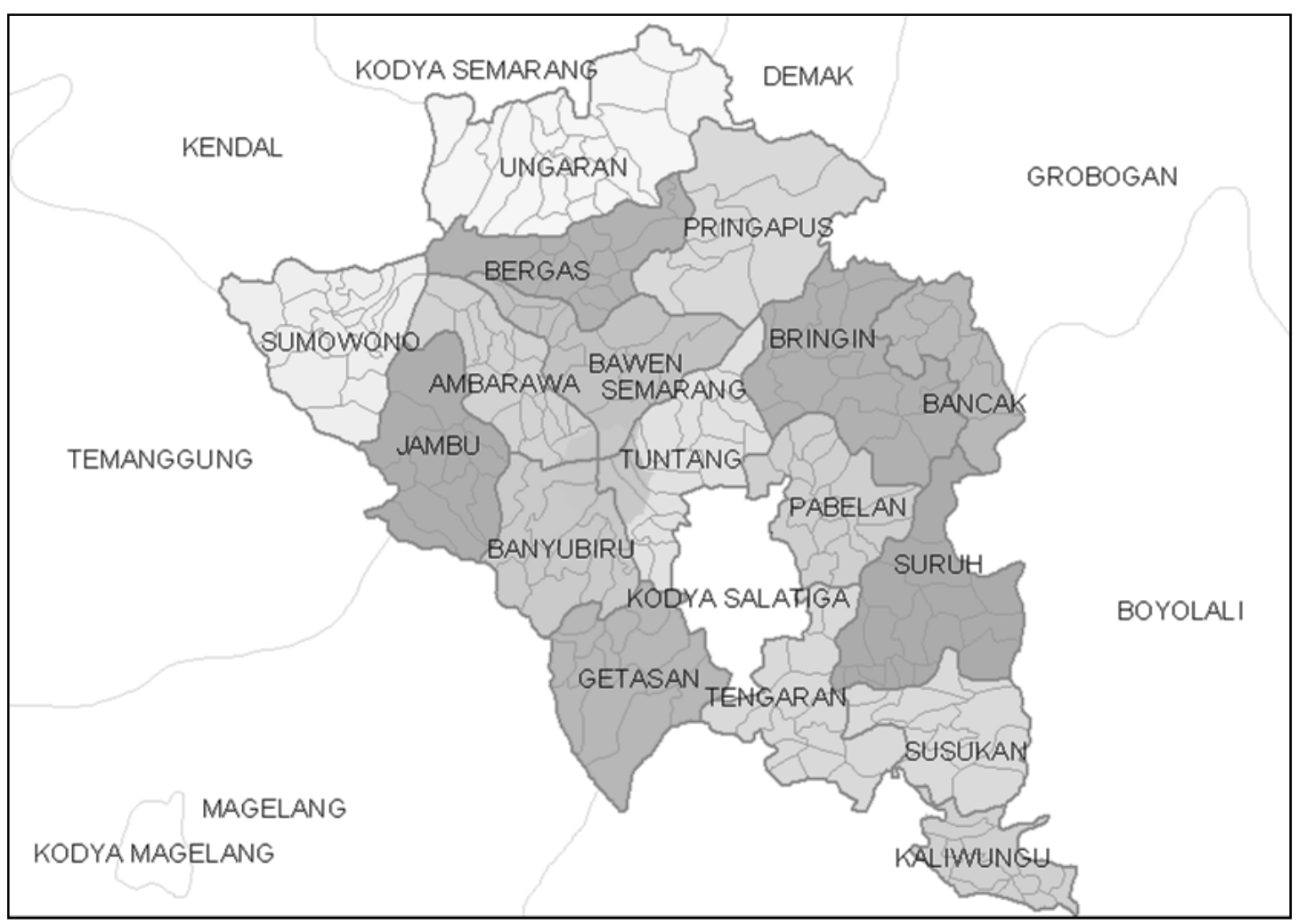

Figure 1. Map of Rawapening.

Source : Book of Technical Planning in Rawapening Tourism,

Board of Regional Planning and Development, Semarang Regency, Central Java Province, Indonesia ( 2009 )

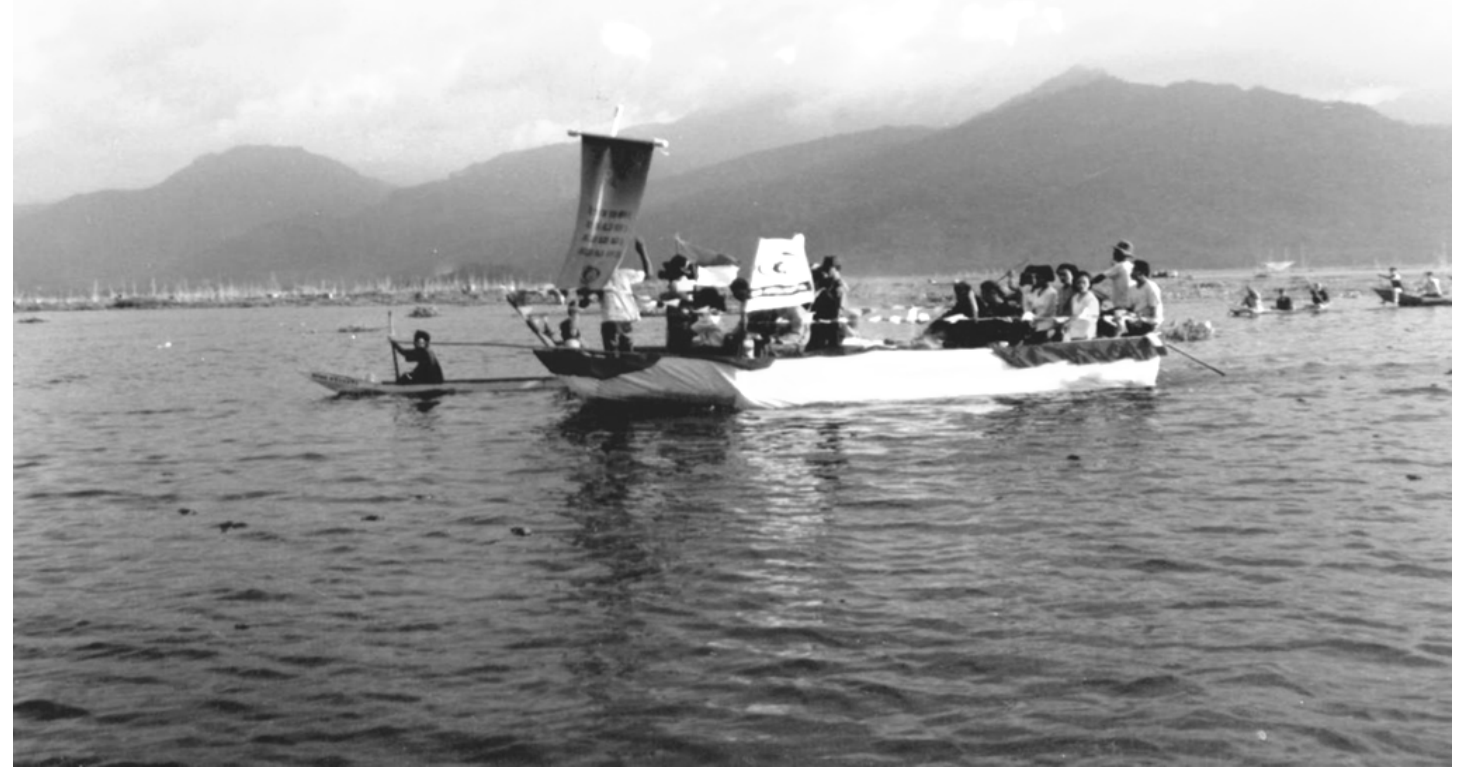

Figure 2. View of Rawapening.

Source : Book of Technical Planning in Rawapening Tourism,

Board of Regional Planning and Development, Semarang Regency, Central Java Province, Indonesia ( 2009 ) 


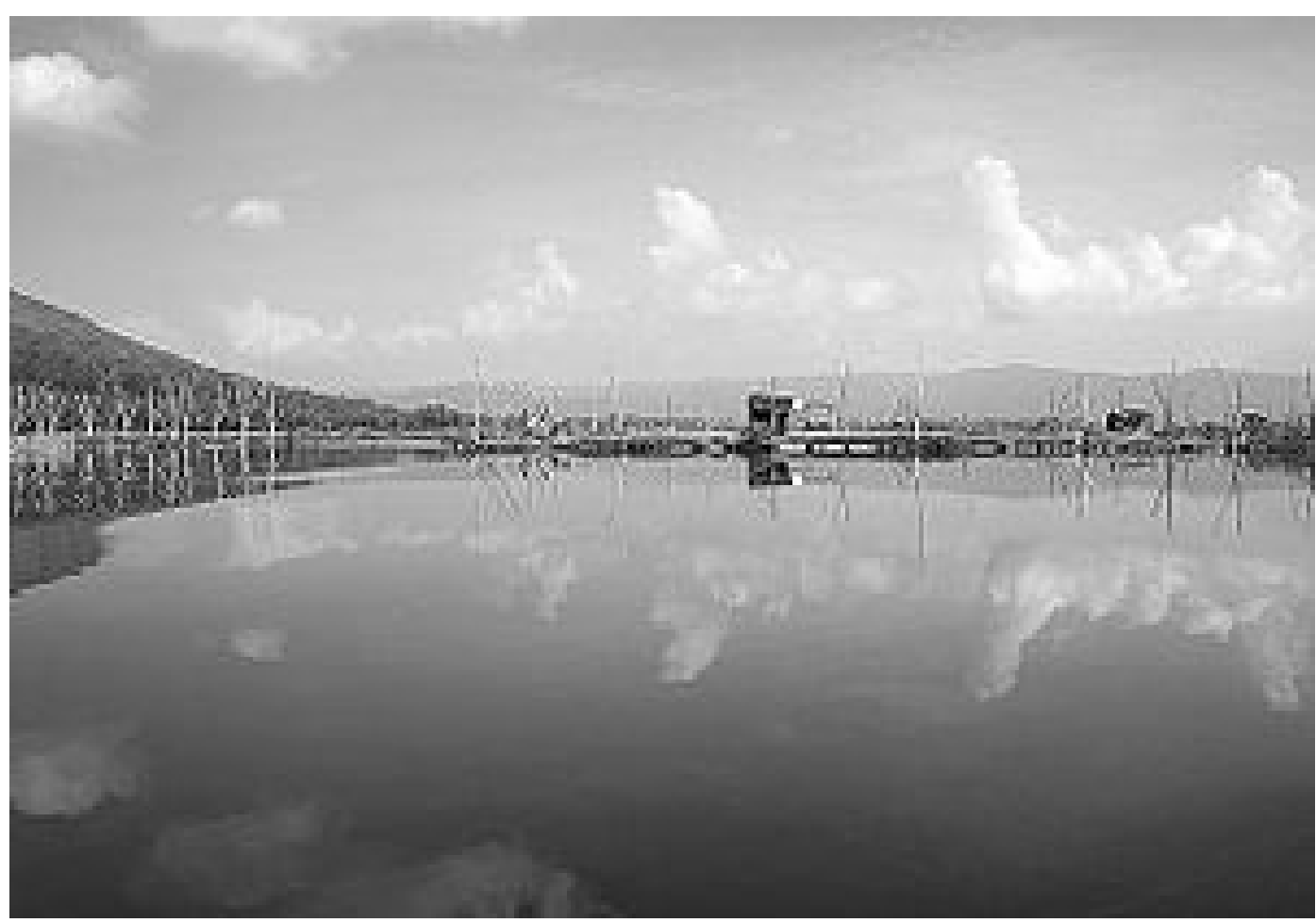

Figure 2. View of Rawapening

[Online] Available: http://id.wikipedia.org/wiki/Rawa_Pening

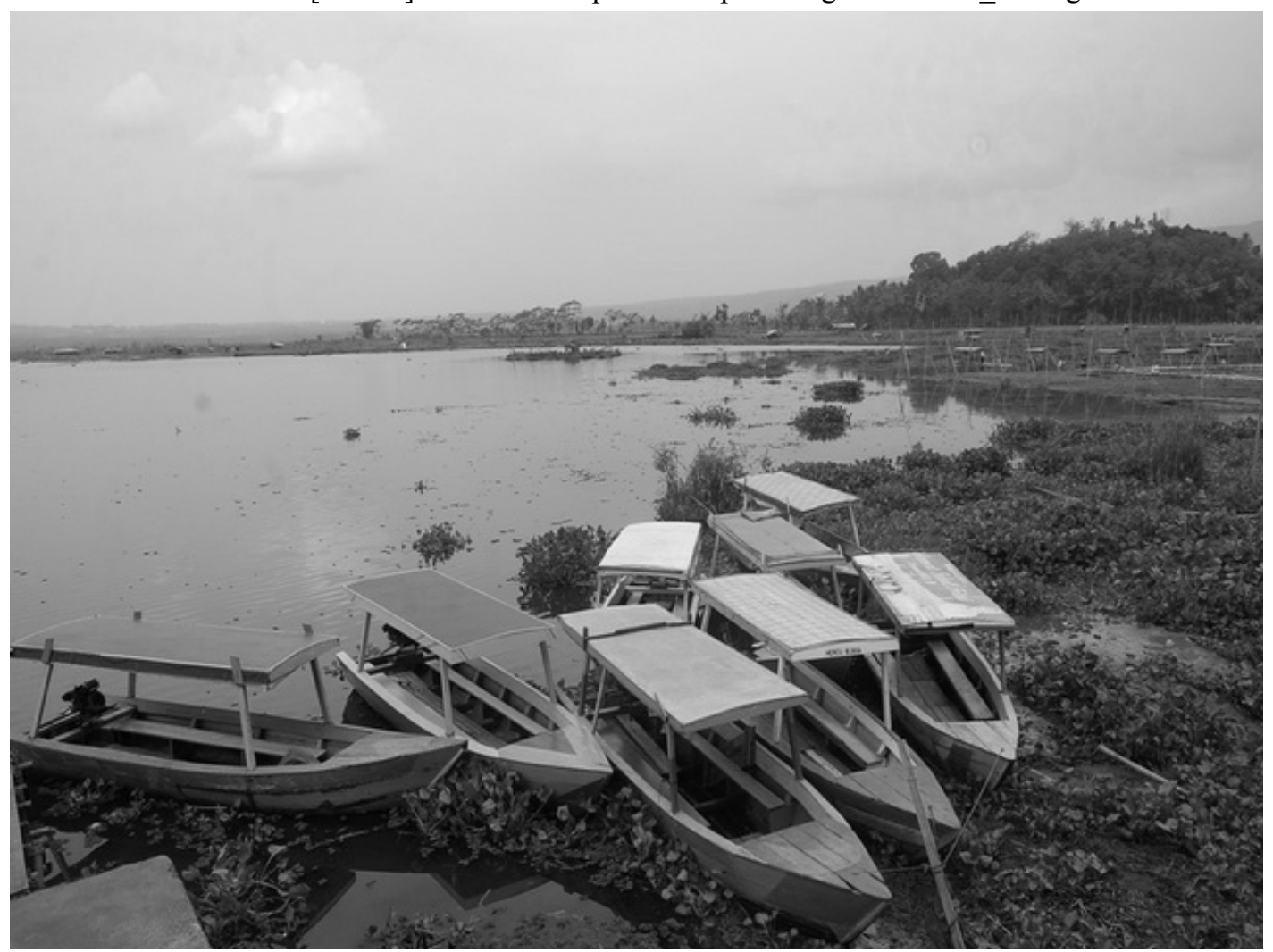

Figure 3. View of Rawapening .

[Online] Available: http://aci.detik.com/readfoto/2010/10/16/230346/1466863/1002/1/rawa-pening 